\title{
SOMATOSENSORY CEREBRAL EVOKED POTENTIALS IN SPINAL CORD DISEASES
}

\author{
By Priv. Doz. Dr med. W. GrünInger and Prof. Dr med. K. RICKeR \\ Reha-Klinikf. Querschnittgelähmte im Krankenhaus Hohe Warte, D 8580 Bayreuth, \\ Neurologische Universitätsklinik, D 8700 Würzburg
}

\begin{abstract}
Somatosensory cortical-evoked potentials (CEP) were investigated in I6 patients with localised myelopathy and in five patients with generalised myelopathy, and then compared with those found in 30 control subjects.
\end{abstract}

Key words: Cortical-evoked Potentials (CEP); Myelopathies.

\section{Introduction}

DAwson (I947) was the first to pick up specific evoked potentials over the cortex (CEP) of the contralateral hemisphere in response to the stimulation of a peripheral nerve. Today, CEPs have been measured in response to the stimulation of various different peripheral nerves (Allison, 1962; Goff et al., 1962; Debeker et al., I964; Giblin, I964; Calmes et al., I97I; Desmedt, I97I; Cracco, I972; Desmedt et al., I973 and others).

The first reports on changes in the CEP seen in diseases of the spinal cord, were made by Alajouanine et al. (1958), Halliday et al. (1963), Giblin (1964), and Bergamini et al. (1965). A striking observation was the fact that patients with dissociation sensibility manifested only slight changes in the CEP. These findings were confirmed by later investigations carried out by Desmedt (I97I), Nakanishi (1974). Baust et al. (1972, I974) made use of the determination of the CEP following segmental stimulation, to localise the level of pathological processes within the spinal cord. We carried out investigations of 16 patients with localised diseases of the spinal cord, and five patients with generalised spinal cord pathology, and compared the results we obtained with a group of 30 healthy test subjects.

\section{Method}

The examination was carried out in a partially darkened room, at a constant temperature of $3 \mathrm{I}^{\circ} \mathrm{C}$. Any peripheral nerve damage was excluded by determining the conduction velocities of the motor and sensory nerves.

\section{Stimulation}

Stimuli were applied to the tibial nerve at the medial aspect of the ankle joint of both legs. For special questions, segmental stimulation was additionaily performed on the trunk.

To carry out stimulation, a bipolar surface electrode (Disa I3 K 62) was employed, the stimulating poles being spaced $25 \mathrm{~mm}$ apart. The intensity of the stimulus was 2-3 times greater than the sensory threshold of intensity. The stimuli consisted of square-wave pulses having a duration of $0.2 \mathrm{msec}$ and were applied at a frequency of $\mathrm{I} / \mathrm{sec}$. 


\section{Recording}

Recording was effected by using two EEG needle electrodes placed in the galea in accordance with the international I0-20 Jasper System (1957), over the sensory 'foot field', the active electrode being located on point $\mathrm{C}_{\mathrm{Z}}$ and the indifferent electrode on the point $\mathrm{F}_{\mathrm{z}}$. The band width of the amplifier employed was between $2 \mathrm{~Hz}$ and Io $\mathrm{kHz}$. A computer (Type Histomat $\mathrm{S}$ manufactured by Intertechnik) having I024 addresses and an analysis time of $300 \mathrm{msec}$, was used as the averager. Each stimulation was performed twice, in order to eliminate artefacts.

The cortical-evoked potentials were recorded in such a way that the negative potential peak $(\mathrm{N})$ pointed upwards, while the positive potential peak $(\mathrm{P})$ pointed downwards (Fig. I).

Following Giblin (1964) the individual potential peaks are identified with $\mathrm{N}$ or $\mathrm{P}$ and are numbered consecutively. The potential peak $\mathrm{P}_{1}$-regularly recorded

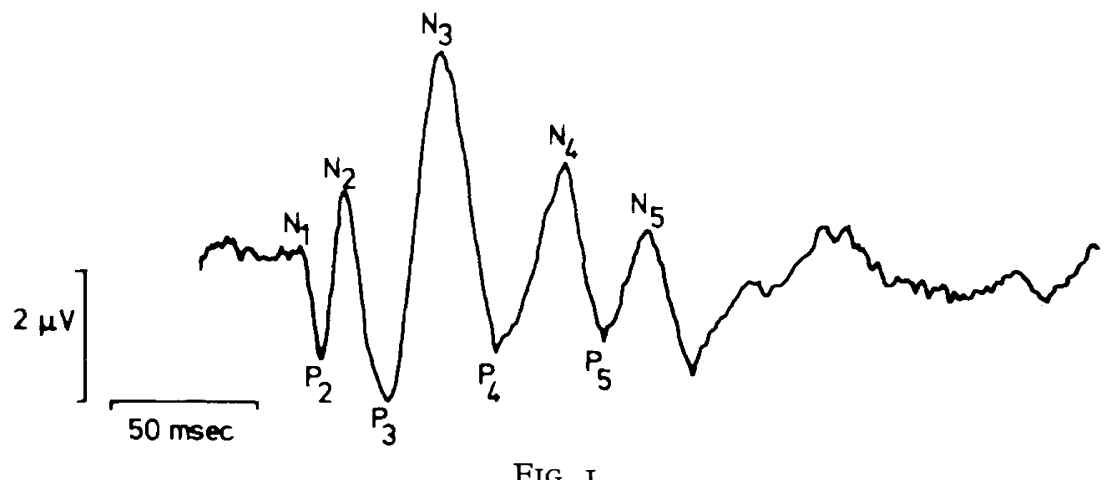

Cortical-evoked responses on stimulation of the tibial nerve. Potential peaks identified in accordance with Giblin (I964).

on stimulation of the median nerve-was not taken into account, since it was picked up in only 33 per cent of the healthy control subjects in response to stimulation of the tibial nerve. The latency of the potential peaks $\mathrm{N}_{1}$ to $\mathrm{N}_{5}$, and the peak-to-peak amplitudes were measured. The potential peaks $\mathrm{N}_{1}$ to $\mathrm{N}_{3}$ were collectively designated as the primary response, the subsequent potentials as secondary response.

\section{Results}

Standard figures: Thirty healthy control subjects, aged between $\mathrm{I} 7$ and 72 years, were examined. The latencies of the primary response $\mathrm{N}_{1}$ to $\mathrm{N}_{3}$ of the CEP following stimulation of the tibial nerve at the ankle were determined accurately in every examination. The potential peaks of the secondary response $\mathrm{P}_{4}$ to $\mathrm{N}_{5}$, were frequently not reliably determinable $\left(\mathrm{N}_{5}\right.$ only in some 6 per cent) with increasing potential duration, so that potential fluctuations after $\mathrm{N}_{5}$ were not taken into account. The mean value of the latencies for $\mathrm{N}_{1}$ is $31.5 \mathrm{msec}$. The range of scatter of the latencies increases continuously from $\mathrm{N}_{1}$ onwards (Table I).

The amplitudes of the primary response increase up to $\mathrm{N}_{3}$, while in the secondary response, the amplitudes decrease. The scatter range is large, so that it was possible to assess the amplitudes only in a bilateral comparison (Table II). 


\section{TABLE I}

Cortical-evoked potentials in response to stimulation of the tibia nerve. Latency of the potential peaks in 30 healthy test subjects

\begin{tabular}{|c|c|c|c|c|c|}
\hline & $\mathrm{N}$ & $\frac{\mathrm{X}}{(\mathrm{msec})}$ & $\begin{array}{l}\text { Scatter } \\
\text { (msec) }\end{array}$ & $\begin{array}{c}\text { 2-s range } \\
\text { (msec) }\end{array}$ & $\begin{array}{c}\mathrm{s}_{\mathrm{x}} \\
(\mathrm{msec})\end{array}$ \\
\hline \multicolumn{6}{|c|}{ Primary response } \\
\hline $\begin{array}{l}\mathrm{N}_{1} \\
\mathrm{P}_{2} \\
\mathrm{~N}_{2} \\
\mathrm{P}_{3} \\
\mathrm{~N}_{3}\end{array}$ & $\begin{array}{l}30 \\
30 \\
30 \\
30 \\
30\end{array}$ & $\begin{array}{l}31 \cdot 5 \\
38 \cdot 6 \\
46 \cdot 9 \\
57 \cdot 1 \\
70 \cdot 5\end{array}$ & $\begin{array}{l}28 \cdot 2-36 \cdot 9 \\
36 \cdot 3-42 \cdot 3 \\
38 \cdot 1-56 \cdot 7 \\
44 \cdot 7-66 \cdot 6 \\
60 \cdot 3-84 \cdot 3\end{array}$ & $\begin{array}{l}27 \cdot 3-35 \cdot 7 \\
34 \cdot 2-48 \cdot 0 \\
40 \cdot 2-53 \cdot 6 \\
47 \cdot 9-66 \cdot 4 \\
60 \cdot 4-60 \cdot 7\end{array}$ & $\begin{array}{l}2 \cdot \text { II } \\
2 \cdot 18 \\
3 \cdot 34 \\
4.62 \\
5 \cdot 06\end{array}$ \\
\hline \multicolumn{6}{|c|}{ Secondary response } \\
\hline $\begin{array}{l}\mathrm{P}_{4} \\
\mathrm{~N}_{4} \\
\mathrm{P}_{5} \\
\mathrm{~N}_{5}\end{array}$ & $\begin{array}{l}30 \\
30 \\
26 \\
20\end{array}$ & $\begin{array}{r}96 \cdot 7 \\
\text { I } 23 \cdot 9 \\
\text { I } 45 \cdot 0 \\
\text { I } 70 \cdot 8\end{array}$ & $\begin{array}{r}73 \cdot 3-\mathrm{I} 22 \cdot \mathrm{I} \\
80 \cdot 4-\mathrm{I} 6 \mathrm{I} \cdot 4 \\
99 \cdot 9-\mathrm{I} 99 \cdot 2 \\
\text { I I } 7 \cdot 6-229 \cdot 9\end{array}$ & $\begin{array}{r}73 \cdot 8 \text { - I I } 9 \cdot 6 \\
84.0-\text { I63.8 } \\
88 \cdot 6-201 \cdot 5 \\
\text { I04.3-237.3 }\end{array}$ & $\begin{array}{l}\text { I I. } 44 \\
\text { I } 9 \cdot 96 \\
28 \cdot 22 \\
33 \cdot 24\end{array}$ \\
\hline
\end{tabular}

TABLE II

Cortical-evoked potentials in response to stimulation of the tibial nerve. Amplitude of the potential peaks in 30 healthy test subjects

\begin{tabular}{|c|c|c|c|c|}
\hline & $\mathrm{N}$ & $\begin{array}{c}\mathrm{x} \\
(\mu \mathrm{V})\end{array}$ & Limit values & $\begin{array}{c}\text { Scatter } \\
(\mu \mathrm{V})\end{array}$ \\
\hline \multicolumn{5}{|c|}{ Primary response } \\
\hline $\begin{array}{l}\mathrm{N}_{1} \\
\mathrm{P}_{2} \\
\mathrm{~N}_{2} \\
\mathrm{P}_{3} \\
\mathrm{~N}_{3}\end{array}$ & $\begin{array}{l}30 \\
30 \\
30 \\
30 \\
30\end{array}$ & $\begin{array}{l}0.27 \\
1 \cdot 85 \\
3 \cdot 32 \\
2 \cdot 59 \\
3.58\end{array}$ & $\begin{array}{l}0.0 I-0.74 \\
0.82-5 \cdot 29 \\
I \cdot I 8-9 \cdot I 7 \\
0.32-5.91 \\
0.97-7.98\end{array}$ & $\begin{array}{l}0 \cdot 73 \\
4 \cdot 47 \\
7 \cdot 99 \\
5 \cdot 59 \\
7 \cdot 01\end{array}$ \\
\hline \multicolumn{5}{|c|}{ Secondary response } \\
\hline $\begin{array}{l}\mathrm{P}_{4} \\
\mathrm{~N}_{4} \\
\mathrm{P}_{5} \\
\mathrm{~N}_{5}\end{array}$ & $\begin{array}{l}30 \\
27 \\
25 \\
20\end{array}$ & $\begin{array}{l}3 \cdot 5 \mathrm{I} \\
2 \cdot \mathrm{I} 5 \\
\mathrm{I} \cdot 46 \\
\mathrm{I} \cdot 25\end{array}$ & $\begin{array}{l}0.87-7 \cdot 68 \\
0.58-6 \cdot 07 \\
0.0-2 \cdot 85 \\
0 \cdot 44-2 \cdot 66\end{array}$ & $\begin{array}{l}6 \cdot 81 \\
5 \cdot 39 \\
2 \cdot 45 \\
2 \cdot 22\end{array}$ \\
\hline
\end{tabular}

\section{CEP in localised myelopathies}

In eight patients with a complete paraplegic syndrome, no cortical-evoked potentials were demonstrable on stimulation of the tibial nerve. On the basis of segmental stimulations, it was possible to carry out an accurate localisation of the levels of the pathological processes, and it was frequently seen that stimulation below the clinical 'paraplegic limit' led to an incipient cortical-evoked response (Fig. 2).

Six patients presenting with an incomplete paraplegic syndrome due to a vascular lesion of the spinal cord, revealed varying changes in the CEP, depending upon the degree of clinical severity or the damage to the afferent tracts.

Table III. In many cases, the clinical syndrome permits conclusions to be drawn as to the pathological-anatomical pattern of injury. In the case of patients 


\section{TABLE III}

Symptomatology and measured data of the CEP in six patients with incomplete paraplegia due to circulatory damage to the spinal cord

\begin{tabular}{|c|c|c|c|c|c|c|c|c|c|}
\hline \multirow{3}{*}{ Patient } & & \multirow{3}{*}{\multicolumn{2}{|c|}{ Diagnosis }} & \multicolumn{3}{|c|}{ Clinical features } & \multirow{3}{*}{$\begin{array}{l}\text { Latency } \\
\mathrm{N}_{1}(\mathrm{~ms})\end{array}$} & \multirow{2}{*}{\multicolumn{2}{|c|}{ Amplitudes }} \\
\hline & & & & Motor power & Pain & Position & & & \\
\hline & & & & & & & & $\mathrm{N}_{2}$ & $\mathrm{~N}_{3}$ \\
\hline \multirow[t]{2}{*}{ K.R.m. } & $23 \mathrm{~J}$ & Haematomyelia & re. & I & ++ & - & $29 \cdot 7$ & 0.54 & 2.65 \\
\hline & & $\mathrm{C}_{2}-\mathrm{C}_{8}$ & li. & 2 & + & - & $30 \cdot 6$ & $2 \cdot 24$ & $2 \cdot 08$ \\
\hline \multirow[t]{2}{*}{ M.K.m. } & $22 \mathrm{~J}$. & Brown-Séquard & re. & I & - & - & $33 \cdot 9$ & $4 \cdot 28$ & $5 \cdot 23$ \\
\hline & & $\mathrm{C}_{6}-\mathrm{C}_{7}$ & li. & 0 & ++ & - & $33 \cdot 6$ & $2 \cdot 54$ & $4 \cdot 27$ \\
\hline \multirow[t]{2}{*}{ A.G.w. } & $64 \mathrm{~J}$. & Myelopathy & re. & I & - & - & $29 \cdot I$ & $2 \cdot 16$ & 2.56 \\
\hline & & from $\mathrm{C}_{4}$ & li. & I & + & + & $48 \cdot 5$ & $2 \cdot 68$ & 0.88 \\
\hline \multirow{2}{*}{ B.R.m. } & $53 \mathrm{~J}$. & Paraplegia & re. & 3 & ++ & - & $3 I \cdot 8$ & 0.96 & $2 \cdot 26$ \\
\hline & & incompl. $\mathrm{Th}_{4}$ & li. & I & ++ & ++ & - & - & - \\
\hline J.E.m. & $52 \mathrm{~J}$. & $\begin{array}{l}\text { Paraplegia } \\
\text { incompl. } \mathrm{Th}_{4}\end{array}$ & & I & + & + & $38 \cdot 4$ & $2 \cdot 06$ & $I \cdot 34$ \\
\hline S.H.m. & $46 \mathrm{~J}$. & $\begin{array}{l}\text { Caisson disease } \\
\text { Conus-S }\end{array}$ & & 2 & + & - & $3 I \cdot 2$ & $2 \cdot 35$ & $3 \cdot 38$ \\
\hline
\end{tabular}




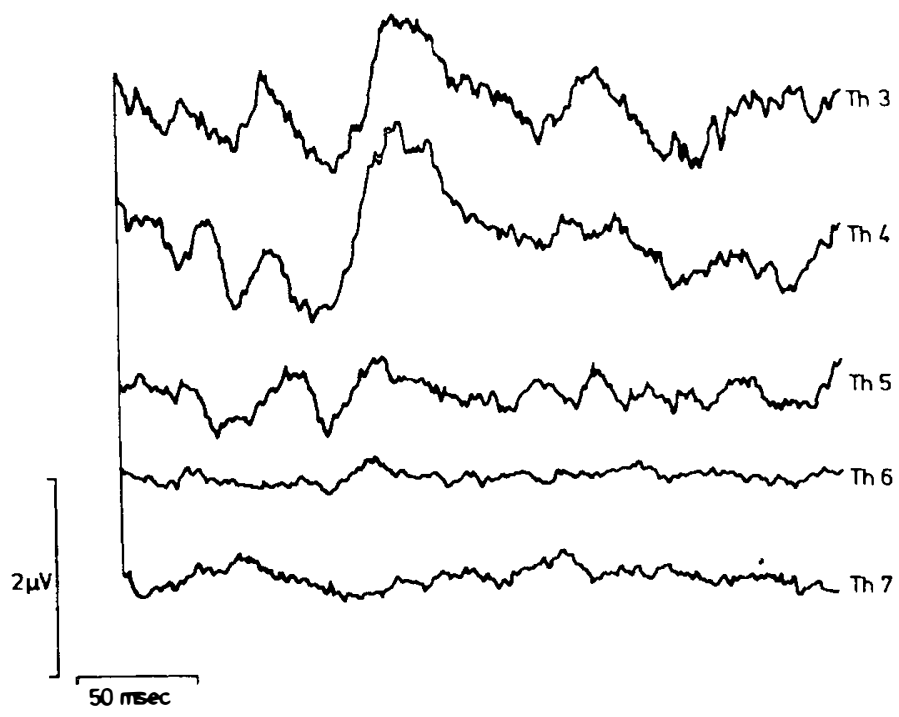

FIG. 2

Patient B.R., 26-years-old: Complete paraplegia at the $\mathrm{Th}_{4}$ level, following compression fracture of the 4 th thoracic vertebra. Segmental stimulation revealed that a CEP is obtained from dermatome $\mathrm{Th}_{5}$.
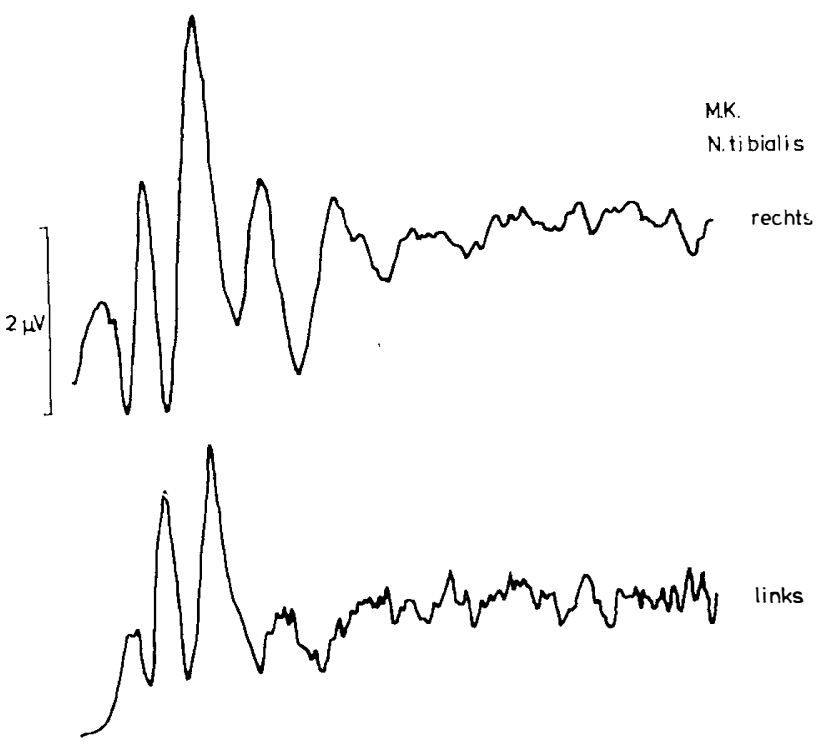

FIG. 3

Patient M.K., male, 22-years-old: Brown-Séquard syndrome at $\mathrm{C}_{6 / 7}$ with dissociated sensory loss on the left side from dermatome $\mathrm{C}_{6}$.

Reduction in the amplitude of the CEP on stimulation of the left tibial nerve. Latencies normal on each side.

N. tibialis $=$ Tibial nerve; rechts $=$ right links $=$ left 
with dissociated sensory loss, normal CEP latencies were found in each case, whilst, in contrast, the amplitudes of the primary and secondary responses were diminished (Fig. 3).

Similar findings were established in two patients presenting with syringomyelia of the cervical spinal cord, in whom a dissociated sensory loss was seen in both legs (Fig. 4).

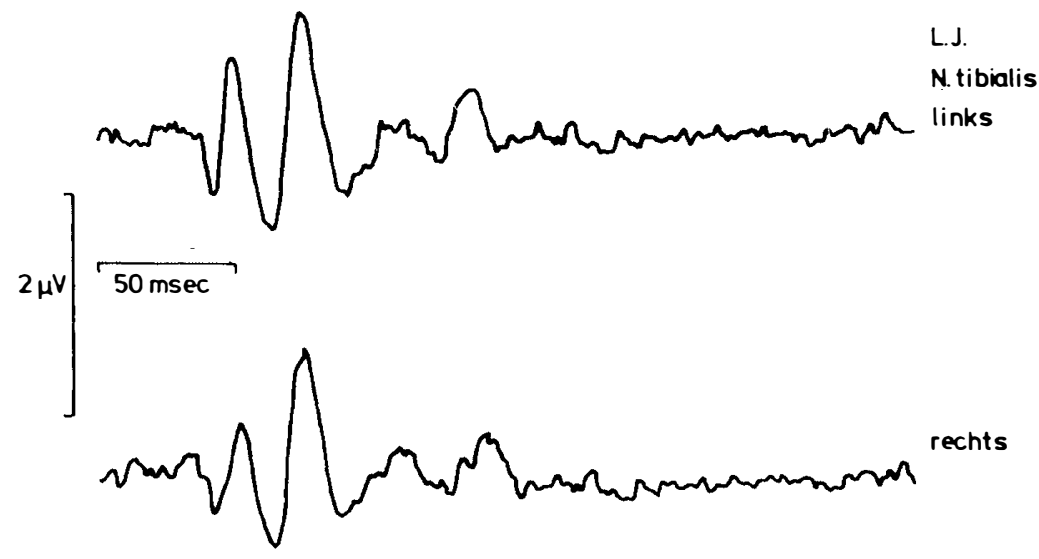

FIG. 4

Patient L.J., male, 45-years-old: Syringomyelia in the cervical spinal cord, $\mathrm{C}_{4}$ to $\mathrm{C}_{8}$. Dissociated sensory loss below $\mathrm{C}_{8}$ on both sides. Reduction of the amplitudes, normal latencies of the CEP.

N. tibialis $=$ Tibial nerve; rechts $=$ right ; links $=$ left

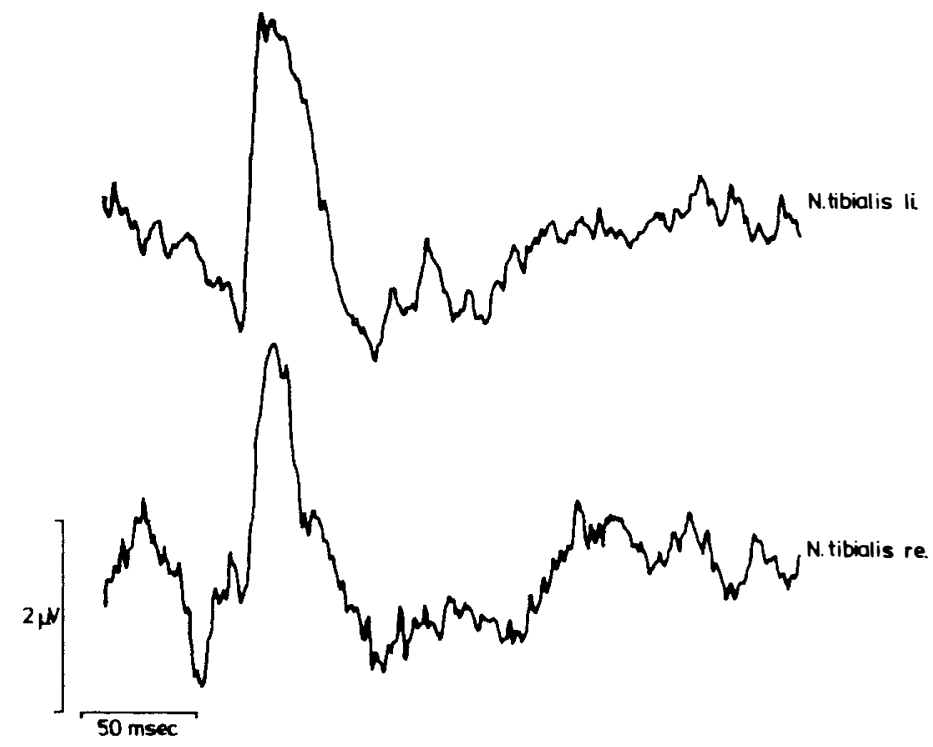

FIG. 5

Patient B.H., male, 50-years-old, tabes dorsalis. Delay in the latencies, and deformation of the CEP.

N. tibialis li. = Left tibial nerve

N. tibialis re. $=$ Right tibial nerve 


\section{TABLE IV}

Symptomatology and measured data of the CEP in five patients with diffuse localisation of myelopathy

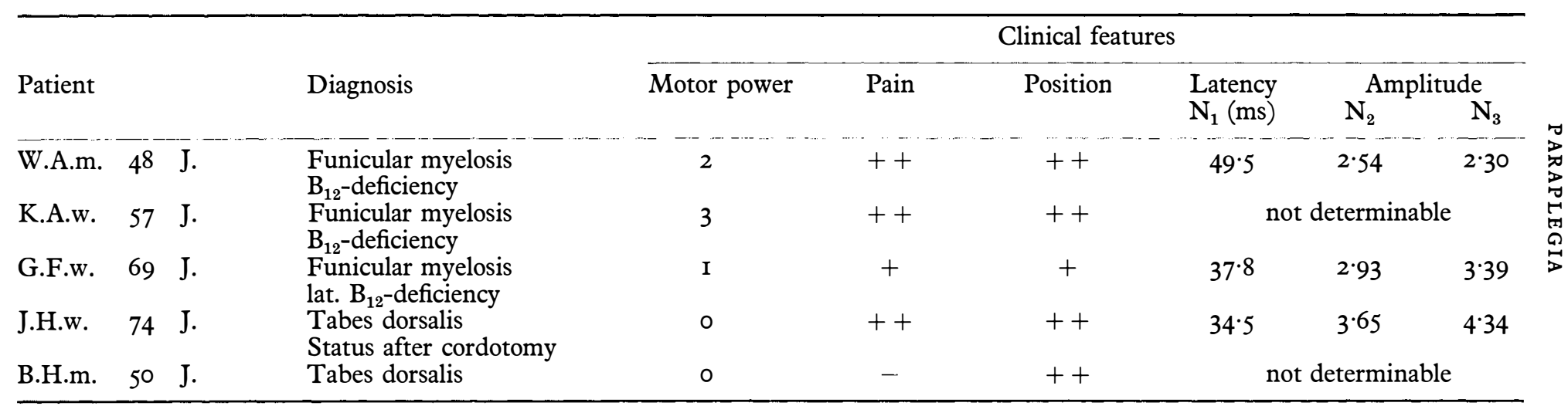

Motoricity: $0=$ none, $3=$ severe disorder Sensitivity: $-=$ none,$++=$ severe disorder 


\section{CEP in patients with generalised myelopathy}

In five patients with generalised pathology of the spinal cord, considerable changes, both in the latencies and in the amplitudes of the CEPs were found (Table IV). Particularly marked were the changes of the CEP in the myelopathies with predominant involvement of the posterior tracts (dorsal columns), as, for example, in patients with tabes dorsalis. The loss of position and vibration sensation, with normal pain and tactile sensation, led to a long delayed latency of the CEP. The potential is deformed, the primary response cannot be accurately delimited (Fig. 5). In the three patients presenting with combined tract pathology, considerable changes in the CEP were also found.

\section{Discussion}

The influence of spinal cord pathology on the cortical-evoked potentials (CEPs) by stimulation of the tibial nerve, can best be recognised in the group of patients with a vascular myelopathy.

In common with Alajouanine et al. (1958) and Baust et al. (1974), we also observed a diminution in the amplitudes of CEP in subjects with dissociated sensory loss. In our patients, the later potential peaks were particularly involved, and this accorded with the results obtained by Tsumoto (I973). The latencies were, by and large, within the normal range. From this, it may be deduced that the sensory stimuli that give rise to the CEP, are conducted largely along the posterior tract (dorsal column). In contrast, the ventrolateral tract appears, in the main, to determine the amplitude and the degree of the secondary response. Grieshop et al. (1970) and Blair et al. (1975), in patients with chronic pain, were able to produce a change in the CEP after stimulation of the tibial nerve, by direct stimulation of the dorsal columns in the lumbar region. They discovered a reduction in amplitudes, in particular of the late potential peaks. There was a direct correlation between the reduction in amplitude and the amelioration of pain. Like Giblin, Bergamini et al., Namerow et al. and Baust et al., we also observed the greatest changes in the CEP in myelopathies where the dorsal columns were severely affected, for example, in funicular myelosis and in tabes dorsalis. In some cases, the deformation of the potential was so marked that the reliable identification of the potential peaks, and therefore a comparison of the latencies with those of the healthy group, was not possible.

In a person with paraplegia where there is loss of all the sensory modalities, there will always be a marked change in the CEP. In those with complete paraplegia, no CEP can be induced by stimulating an area of skin distal to the 'sensitivity boundary'. Our findings with respect to segmental stimulation, confirm the reports of Baust et al. (1974), namely, that, by this means, an accurate localisation of the level of the process in the spinal cord can be obtained. In patients with cervical myelopathy, Matsukado et al. (1976) described a marked delay in the latencies of the CEP on stimulation of the median nerve. The CEP induced by stimulating the nerves in the arm, however, is, we believe, unsuitable for assessing cervical myelopathy, since, according to Desmedt et al. (I974), a radicular disorder can also lead to a delay in the CEP, and thus any conclusions regarding a circumscribed spinal cord lesion is no longer possible. In the case of diffuse diseases of the spinal cord, in particular those caused by lack of vitamin $\mathrm{B}_{12}$, the peripheral, sensory and motor nerve conduction rates must, of course, be determined in order to exclude a neuropathic process as the cause of a change in the CEP. At the same 
time, it is essential to exclude a disturbance in the central transmission of the stimulus in the brain-stem and in the cerebrum. The technique proposed by Ertekin (1976), involving the direct pick-up of the evoked potentials by introducing electrodes into the spinal canal, cannot yet be employed for clinical diagnosis.

\section{Summary}

Cortical-evoked potentials (CEPs) induced by the stimulation of the tibial nerve, were investigated in 16 patients with localised myelopathy, and in five patients with generalised myelopathy, and compared with the results obtained in 30 healthy test subjects.

The investigations show that the pulses that give rise to the CEP, are conducted mainly by the posterior columns. Damage to the ventrolateral tracts, in contrast, leads only to a reduction in the amplitude of the CEPs.

If account is taken of possible artefacts and misinterpretations, the method described is highly suitable for determining the level of a lesion in complete paraplegia and for obtaining information as to the size and extent of spinal cord damage in myelopathies.

\section{RÉSUMÉ}

Cérébraux évoqués potentiels (CEP) par stimulation du nerf tibial ont été étudiés chez I6 patients avec une affection spinale localisée et chez 5 patients avec une myélopathie generalisée. Les résultats ont été comparées avec les resultats obtenues chez 30 sujets normaux. La comparaison des resultats fait voir que les cordons postérieurs sont la voie principale des impulses evoquent la résponse cérébrale. L'affection du cordon antérieurelaterale cause une diminuation des amplitudes du CEP.

En tenant compte des artéfactes possibles et des interprétations fautives la méthode déscribée est propre pour déterminer le niveau de la lésion spinale chez les parplégiques et pour éclaircir l'extension des lésions de la moelle chez les myélopathies.

\section{ZUSAMMENFASSUNG}

Cortikale evozierte Potentiale (CEP) durch Reizung des N. tibialis wurden bei I6 Patienten mit lokalisierter Myelopathie und bei 5 Patienten mit generalisierter Myelopathie untersucht und mit den Ergebnissen von 30 gesunden Kontrollpersonen verglichen. Die Untersuchungen zeigen, daß die für die Entstehung des CEP verantwortlichen Impulse hauptsächlich über die Hinterstrangsbahnen geleitet werden. Schädigungen der Vorderseitenstrangbahn führen dagegen nur zu einer Amplitudenreduktion des CEP. Bei Berücksichtigung möglicher Artefakte und Fehlbeurteilungen eignet sich die beschriebene Methode gut zur Höhenbestimmung bei kompletter Querschnittslähmung sowie zur Aussage über Umfang und Ausdehnung der Rückenmarksschäden bei Myelopathien.

\section{REFERENCES}

Alajouanine, T., Scherrer, J., Barbizet, J., Calvet, J. \& Verley, R. (I958). Potentiels évoqués corticaux chez des sujets atteints de troubles somesthesiques. Rev. neurol., 98, 757 .

Allison, T. (1962). Recovery function of somatosensory evoked responses in man. Electroenceph. clin. Neurophysiol., 14, 33 I.

Baust, W., IlsEN, H. W., Jörg, J. \& WAMBACH, G. (I972). Höhenlokalisation von Rückenmarksquerschnittssyndromen mittels corticaler Reizantwortpotentiale. Nervenarzt, 43, 292.

BAUST, W., JöRG, J. \& LANG, J. (1974). Somatosensorische corticale Reizantwortpotentiale bei adäquater Reizung und neurologischen Erkrankungen mit spezifischen Sensibilitätsstörungen. Z. $E E G-E M G, 5,3 \mathrm{I}$.

Bergamini, L., Bergamesco, B., Fra, L., Gandiglio, G., Mombelli, A. M. \& Mutani, R. (I965). Somatosensory evoked cortical potentials in subjects with peripheral nervous lesions. Electromyograph, 5, I2I. 
Blair, R. D., LeE, R. G. \& VANDERLinden, G. (I975). Dorsal column stimulation, its effect on the somatosensory evoked response. Arch. Neurol., 32, 826.

Calmes, R. L. \& CRACCO, R. Q. (I97I). Comparison of somatosensory and somatomotor evoked responses to median nerve and digital nerve stimulation. Electroenceph. clin. Neurophysiol., 31, 547.

CracCo, R. Q. (I972a). The initial positive potential of the human scalp-recorded somatosensory evoked response. Electroenceph. clin. Neurophysiol., 32, 623.

Cracco, R. Q. (I972b). Travelling waves of the human scalp-recorded somatosensory evoked response: effects of differences in recording technique and sleep on somatosensory and somatomotor responses. Electroenceph. clin. Neurophysiol., 33, 557.

Dawson, G. D. (I947). Investigations on a patient subject to myoclonic seizures after sensory stimulation. F. Neurol. Neurosurg. Psychiatr., Io, I4I.

DebeCKer, J. \& Desmedt, J. E. (1964). Les potentiels évoqués cérébraux et les potentiels de nerf sensible chez l'homme et l'utilisation de l'ordinateur nummérique Memotron 400-B. Acta neurol. belg., 64, I2I2.

DESMEDT, J. E. (I97I). Somatosensory cerebral evoked potentials in man. In Handbook of Electroenceph. clin. Neurophysiol. Rémond (ed.), 9, 55.

Desmedt, J. E., Noel, P., Debecker, J. \& NamÉche, J. (1973a). Maturation of afferent conduction velocity as studied by sensory nerve potentials and by cerebral evoked potentials. Electromyography and clin. Neurophysiol., 2, 52.

Desmedt, J. E. \& NOEL, P. (I973b). Average cerebral evoked potentials in the evaluation of lesions of the sensory nerves and of the central somatosensory pathway. In New Developments in Electromyography and clin. Neurophysiol., 2, 352.

Desmedt, J. E., BRunko, E., DebeCKER, J. \& CARMeliet, J. (I974). The bandpass required to avoid distortion of early components when averaging somatosensory evoked potentials. Electroenceph. clin. Neurophysiol., 37, 407.

ERTEKIN, C. (I976 II). Studies of the human evoked electrospinogram. II. The conduction velocity along the dorsal funculus. Acta neurol. scandinav., 53, 2 I.

Giblin, D. R. (I964). Somatosensory evoked potentials in healthy subjects and in patients with lesions of the nervous system. Ann. N.Y. Acad. Sci., I12, 93.

GoFF, W. R., RosNER, B. S. \& AlLISON, T. (I962). Distribution of cerebral somatosensory evoked responses in normal man. Electroenceph. clin. Neurophysiol., I4, 697.

Grieshop, J. (I970). Spinal electroanaesthesia: its relationship to somatosensory cerebral evoked potentials. Excerpta Medica, 2, 33 .

Halliday, A. M. \& Wakefield, G. S. (I963). Cerebral evoked potentials in patients with dissociated sensory loss. F. Neurol. Nuerosurg. Psychiatr., 26, 2 I I.

Halliday, A. M. (1967). Changes in the form of cerebral evoked responses in man associated with various lesions of the nervous system. Electroenceph. clin. Neurophysiol. Suppl., 25, 178 .

JASPER, H. H. (I957). The ten-twenty-system of the international federation. Electroenceph. clin. Neurophysiol., 27, 37 I.

Tsumoto, T., Hirose, N., Nonaka, S. \& Takahashi, M. (I973). Cerebrovascular disease: changes in somatosensory evoked potentials associated with unilateral lesions. Electroenceph. clin. Neurophysiol., 35, 463. 